JOURNAL OF SECURITY AND SUSTAINABILITY ISSUES ISSN 2029-7017 print/ISSN 2029-7025 online

2019 December Volume 9 Number 2 http://doi.org/10.9770/jssi.2019.9.2(23)

Scopus

\title{
ASSESSMENT OF CONVERGENCE PROCESSES OF SOCIAL-ECONOMIC SECURITY INDICATORS IN LATVIAN MUNICIPALITIES
}

\author{
Andrey Smirnov', $^{\prime}$ Olga Lavrinenko², Alina Ohotina ${ }^{3}$, Halina Shmarlouskaya ${ }^{4}$, Alina Betlej ${ }^{5}$

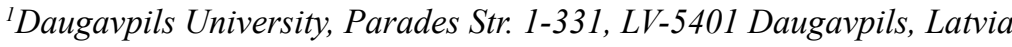 \\ ${ }^{2,3}$ Institute of Humanities and Social Sciences, Daugavpils University, \\ Parades Str. 1-421, Daugavpils, LV-5401, Latvia \\ ${ }^{4}$ Sociology and Economy Department, Daugavpils University, Parades Str. 1-331, LV-5401 Daugavpils, Latvia \\ International Business Department, Belarusian State Economic University, 2 \\ 20070, 26, Partizanski Av, Minsk, Republic of Belarus \\ ${ }^{5}$ Institute of Sociology, John Paul II Catholic University of Lublin, Al. Ractawickie 14, 20-950 Lublin, Poland

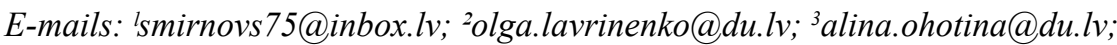 \\ 'galina.shmarlovskaya@gmail.com; ${ }^{5}$ alinabetlej@kul.lublin.pl
}

Received 16 January 2019; accepted 26 Novemeber 2019; published 30 December 2019

\begin{abstract}
The aim of the research is to assess convergence processes of a social-economic security indicator in Latvian municipalities and its components in the period $2011-2015$, calculated as an integral indicator on the basis of primary statistical indicators. The relevance of the research is determined by the fact that social-economic security establishes not only the sustainable economic development of the country as a whole, but also the state of protection from internal and external threats. Municipalities, implementing their autonomous functions, are primary guarantors of social-economic security of the people. The convergence of social-economic security of municipalities implies the process of their convergence in time according to the values of the level of social-economic security ${ }^{1}$.
\end{abstract}

Keywords: investment climate; investment potencial; investment security; sustainability

Reference to this paper should be made as follows: Smirnov A., Lavrinenko O., Ohotina A., Shmarlouskaya H., Betlej, A. 2019. Assessment of Convergence Processes of Social-Economic Security Indicators in Latvian Municipalities. Journal of Security and Sustainability Issues, 9(2): 663-674. http://doi.org/10.9770/jssi.2019.9.2(23)

JEL Classifications: L26, M21, O11, R11

\section{Introduction}

The evolution of the concept of social-economic security should be considered, first of all, from the viewpoint of ideas about the security phenomenon at different stages in the formation of scientific and philosophical views. Therefore, when considering the category "security" in philosophical retrospect, we can observe the diversity of its content. However, there are also common features.

Security always has an application area, it is of a subject-object nature. If we consider security as an object, its subject at different stages in the formation of scientific ideas about this phenomenon at different times became a person, state, political system, welfare, or economic relations.

\footnotetext{
1 This article is published within research project of Daugavpils University "Assessment of Social-Economic Security of Administrative Areas of Latvian Municipalities in Dinamic of 2011 - 2016” No 14-95/6
} 
Security is a multi-level concept. In a philosophical retrospect, it is considered at least at two levels: a microlevel or personal security and a macro-level or security of society, or a state (e. g. Masood et al., 2019; Moumen et al., 2019; Rezk et al., 2019; Fabus et al., 2019; Mikhaylov et al., 2018; Nikitina et al., 2018; Śkuflić et al, 2018; Filipishyna et al., 2018; Kalyugina et al., 2018; Tvaronavičienė 2019). Since the second half of the 19th century, personal security, security of society and the state have not been considered separately: they are interrelated and interdependent. If any objective or subjective reasons pose a threat at a macro level, they also pose a threat at a micro level. At the same time, underestimating the importance of security at a micro level can act as a catalyst for a failure of security at a macro level. There is a lot of attention to the economic security at micro level (Abdullah et al, 2019, Cristiano Freitas Gomes et al., 2019; Olayinka A. Abiodun et al., 2019; Veli Sibiya., \& Tumo Kele 2019; Schwarz 2018; Energy Transformation towards Sustainability, 2019).

Security is always related to the satisfaction of needs. Satisfaction, first of all, of social-economic needs - the needs for economic and social benefits, is important for the subject of our research. Security is always related to the absence of threats. Threats are classified according to the system of micro- and macro-levels, and depend on the system of political and economic structure of the state. Security always implies protection, that is, some kinds of forms and conditions that protect the object from destructive interference. Security is considered as the state of harmony, tranquility, and balance of the interacting parties.

The development of the concept "social-economic security" mainly happened at macro- and micro-levels. Representatives of old economic schools almost never dealt with a meso-level. Over time, the economic and social components of the research subject are increasingly becoming interpenetrating concepts: changes in one, certainly lead to dynamics in the other. Therefore, it does not seem rational to consider economic and social security separately. Due to versatile and multidimensional features of the phenomenon, in the world there is no generally accepted definition of social-economic security, although it is possible to identify some features that provide a general picture of what this phenomenon means.

First, social-economic security is a complex and dynamic concept. This complexity appears, on the one hand, because of a lot of economic, social, and financial processes this concept includes. On the other hand, the complexity is determined by the globalization processes and fast rates of economic processes and phenomena at both national and global levels.

Second, social-economic security should be interpreted as:

- a significant factor of national security that provides resources and a dynamic balance for other components of this system;

- one of the indicators of national, regional, and global security that is the purpose of every person, community, national state, etc.;

- a priority task of governments, regional, and international organizations that strive to provide and guarantee global security of an individual;

- a state of a national economy understood as a source and foundation for elimination of poverty, starvation, social and economic inequality between both individuals and regions within one country.

Third, social-economic security means protection of vitally important interests of a society, country, and citizens, as well as national values and way of living from external and internal threats.

Fourth, social-economic security is a fundamental human right. It is the condition when risks and threats are kept under control in order to protect individuals and communities.

Fifth, social-economic security is a resource necessary for everyday life of individuals and communities in order to achieve their personal or collective aspirations.

Sixth, social-economic security is the result of interaction between external and internal factors that promote the 
processes of production, distribution, and consumption of goods and services produced by a national economy. Seventh, government and non-government organizations play an important role in the achievement of socialeconomic security at national as well as regional and global levels.

Analyzing the definitions of social-economic security, we can state that the existing definitions do not include a level differentiation, although it is obvious that the content of the concept of social-economic security at macro, meso, and micro levels will be different. The authors of the research believe that it would be useful to introduce a level differentiation of the concept "social-economic security" on the basis of the fact that goals, objectives, and, most significantly, indices or factors of this indicator will be different for subjects at different levels.

Therefore, on the basis of the outcomes of the analysis, it is possible to provide the following definition: socialeconomic security of municipal administrative areas is a complex category which is based on the ability of a municipal government to establish mechanisms for implementation of its autonomous functions and spheres of activity, to ensure social-economic security on the basis of a sustainable growth of its indicators, as well as to contribute to a maximum satisfaction of the infrastructure needs of the residents and entrepreneurs on its territory (Lavrinenko et al. 2016; Smirnovs et al. 2018; Ohotina et al. 2018a).

Therefore, it is particularly important to establish an adequate model of social-economic security which allows describing the state of economy at macro and meso levels, carrying out analysis and forecast, and as a result identifying the best possible priorities for the strategy of social-economic security in Latvian municipalities. State administration bodies also need the established model of social-economic security in order to support the decision-making process in the sphere of macroeconomic policy and development of measures for regulating market economy.

The methodological basis of the research are works of both western reaserachers and researchers from different countries in Central and Eastern Europe (Rehm and Schlesinger 2010; Hacker 2012; Buzan 2007; Tvaronavičienė 2018a, 2018b 2019, Tvaronavičienè et al. 2018; Senchagov 2002; Tambovcev 1995; Lavrinenko et al. 2016; Lavrinenko 2016 Ohotina et al. 2018b, Gagarina et al. 2019).

\section{Design and the sample of the research}

Social-economic security is a complex social-economic category; therefore, primary statistical indicators for the regions under study may be presented in the following way:

$$
X=\left[\begin{array}{l}
x_{11}, x_{12}, \ldots, x_{1 n} \\
\ldots \ldots \ldots \ldots \ldots \ldots . \\
x_{i 1}, x_{i 2}, \ldots, x_{i n} \\
\ldots \ldots \ldots \ldots \ldots \ldots . . \\
x_{m 1}, x_{m 2}, \ldots, x_{m n}
\end{array}\right],
$$

where $m$ is a number of regions, $n$ is a number of indicators which characterise social-economic security (Kosiedovskis, Lavrinenko 2014; Lavrinenko 2015).

Taking into account various units for measuring primary indicators, it is necessary to unify the data. The authors carry out the unification on the basis of the linear scaling principle, as a result of which the area of possible values is determined by the interval [0;10] by formula (Lavrinenko, Lavrinoviča 2013):

$$
x_{i j}^{\prime}=\frac{x_{i j}-x_{\min j}}{x_{\max j}-x_{\min j}} \cdot 10
$$


- by indicators-stimulants and

$$
x_{i j}^{\prime}=\frac{x_{\max j}-x_{i j}}{x_{\max j}-x_{\min j}} \cdot 10
$$

- by indicators-destimulants, where $x_{i j}^{\prime}-$ a unified value of the indicator " $\mathrm{j}$ ” for a municipality "i $\mathrm{i}$, $x_{\min }$ and $x_{\max }$ - the lowest (the worst) and the biggest (the best) value of the primary indicator in the period under study.

The structure of the overall indicator of social-economic security consists of 10 components which include the following primary statistical indices: general economic component F1 - total income of a municipality, total expense of a municipality, a number of economically active commercial communities per 1,000 inhabitants, a number of economically active self-employed individuals per 1,000 inhabitants, a number of economically active farm households per 1,000 inhabitants; investment component F2 - the EU funding per 1,000 inhabitants, a total sum of direct foreign investment, a number of projects per 1,000 inhabitants; industrial component F3 - income tax (a municipality's share), a number of income tax payers at a place of a company registration, a collected sum of income tax per 1 inhabitant at a place of a company registered address, advertisement tax, tax on trade in public places, a number of registered companies, a number of liquidated companies; educational component F4 - municipality's expense on education, a number of pre-school educational institutions, a number of general education institutions, a number of programmes implemented at vocational schools; infrastructure component F5 - a municipality's expense on public maintenance of a territory, immovable property tax, general density of motorways; ecological component F6 - a municipality's expense on environment protection; cultural and recreational component F7 - a municipality's expense on leisure, culture, and religion, revenue from selling tickets, tax on gambling; employment component F8 - a level of unemployment, a number of employers, a number of income tax payers at an employee's declared address, a collected sum of income tax per 1 inhabitant at an employee's declared address, a share of long-term unemployed persons of the total number of unemployed persons; law enforcement F9 - a municipality's expense on ensuring public order, a number of crimes per 1,000 inhabitants, a number of serious crimes per 1,000 inhabitants; insuring of social protection and healthcare F10 - a municipality's expense on the social sphere, a number of households receiving housing benefits, a number of benefits on guaranteed level of income, a number of persons with a low income status (\% out of total number of inhabitants), a share of inhabitants who receive social services (\% out of total number of inhabitants), a municipality's expense on medicine (Smirnovs et al. 2018).

Calculation of the indicator of social-economic security was carried out on the basis of the method of sums of the factors that characterise a municipality's spheres of activity which in turn were calculated as a sum of unified statistical indicators included in every sphere:

$$
X_{i}=\sum_{j=1}^{5} F 1_{i j}+\sum_{j=1}^{3} F 2_{i j}+\ldots+\sum_{j=1}^{6} F 10_{i j}
$$

where $i=\overline{1,119}, X_{i}-$ a complex assessment of social-economic security for a municipality $\mathrm{i} ; F_{i j}^{\prime}-$ the value of a factor of social-economic security characterizing every sphere of activity of a municipality (a component), where these factors are calculated as a sum of statistical indicators that characterize them (Smirnovs et al. 2018).

Concergence of municipalities' social-economic security imples the process of their converging according to the values of the level of social-economic security. Two concepts of convergence, interrelated but determining different effects, are mainly used: $\beta$-convergence (Baumol,1986; Barro R.J., Sala-i-Martin X. 1992, p. 223 - 251) and $\sigma$-convergence (Sala-i-Martin 1996a, p.1325-1352; Sala-i-Martin 1996b, p.1019-1036; Islam 2003). 
According to $\beta$-convergence, regions with low absolute values of the indicator under study at the initial period of time are characterised by on average a higher growth rate of this indicator during the process of integration. In order to evaluate $\beta$-convergence, growth-initial level regressions are used:

$$
y_{i}=\mathrm{a}+\beta \ln \left(x_{i t-T}\right)+\mathrm{e},
$$

where $x_{i t-T}$ - an indicator at the point of time preceding the current point of time $t$ at $T$ periods (as a rule, the initial period of integration), $\beta$ - a coefficient to be evaluated, $y_{i}$-average growth rates in $i$ - region over $T$ periods, calculated as $\ln \left(y_{i t}\right) / \ln \left(y_{i t-T}\right)$, e- a random deviation. The value of the $\beta$ coefficient is an indicator of convergence. If $\beta<0$, a high level of the indicator at the initial time period correlate with relatively lower growth rates (Čizo, et al., 2018).

Unlike $\beta$-convergence, $\sigma$-convergence presupposes the decrease with time in a standard deviation of the indicator's value which levels the discrepancy between regions. Another indicator that is often used when there is a trend in time series is the relation of a standard deviation to average (variation coefficient). $\beta$-convergence(i.e. a quicker growth of indicators in the states with lower values of this indicator at the initial period) does not necessarily lead to the decrease in inequality on the indicator under study, namely to $\sigma$-convergence (Barro, Sala-iMartin 1991, 1992). It happens when a group of regions with the initially low absolute values of the indicator constantly changes places with the states with the initially higher absolute values of the indicator, although the overall level of gap between these regions is permanent (Sala-i-Martin, 1996a, Sala-i-Martin 1996b, Barro., Sala-I-Martin 1991, Barro, Sala-I-Martin, 1995).

The authors used the relative indicators of the variation: the coefficient of range $\left(K_{R}\right)$ and the coefficient of variation $\left(V_{\sigma}\right)$. Their calculation is as follows:

$$
\begin{aligned}
& K_{R}=\frac{X_{\max }-X_{\min }}{\bar{x}} ; \\
& \left(V_{\sigma}\right)=\frac{\sigma}{\bar{x}},
\end{aligned}
$$

where $\delta$ - a standard deviation, $\bar{x}$ - an average value, $X_{\max }$ and $X_{\min }$ - the largest and smallest value of the characteristic in the selection (Čizo et al. 2018).

The increase of the coefficient of range and coefficient of variation directly signifies the enhancement of the characteristic in the population under study. Therefore, analysing dynamics of the coefficient of range, coefficient of variation, and the sign of the coefficient $\beta$ in the growth-initial level regressions, it is possible to provide a qualitative characteristic of the process of growth of the existing differences in the sphere of social-economic security in Latvia's municipalities in the period $2011-2015$.

\section{Research results}

In order to carry out a dynamic analysis of social-economic security of administrative areas in Latvia's municipalities, the results for 2011, which are shown on Figure 1 are taken as basic indicators. They are provisionally divided into quintiles. Territories with the best indicators of social-economic security are coloured white (quintile 5), territories with the worst indicators - black (quintile 1) (Smirnovs et al. 2018). 


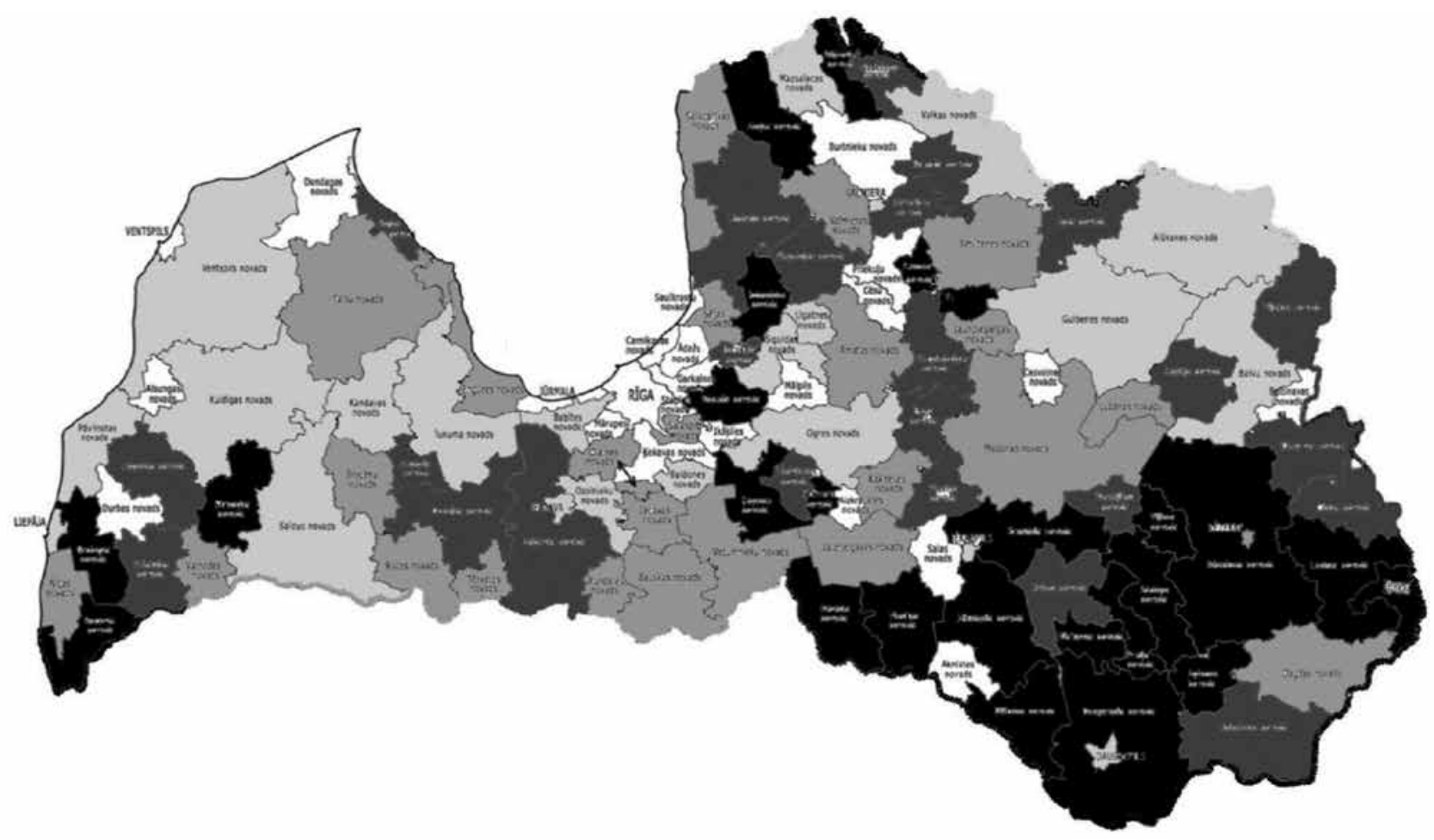

Figure 1. Social-economic security of Latvia's municipal territories according to the data for 2011

Source: Smirnovs, Lavrinenko, Tumalavičius 2018

In order to carry out a dynamic analysis of social-economic security of administrative areas in Latvia's municipalities, the results for 2015, which are shown on Figure 3 are taken as comparison indicators.

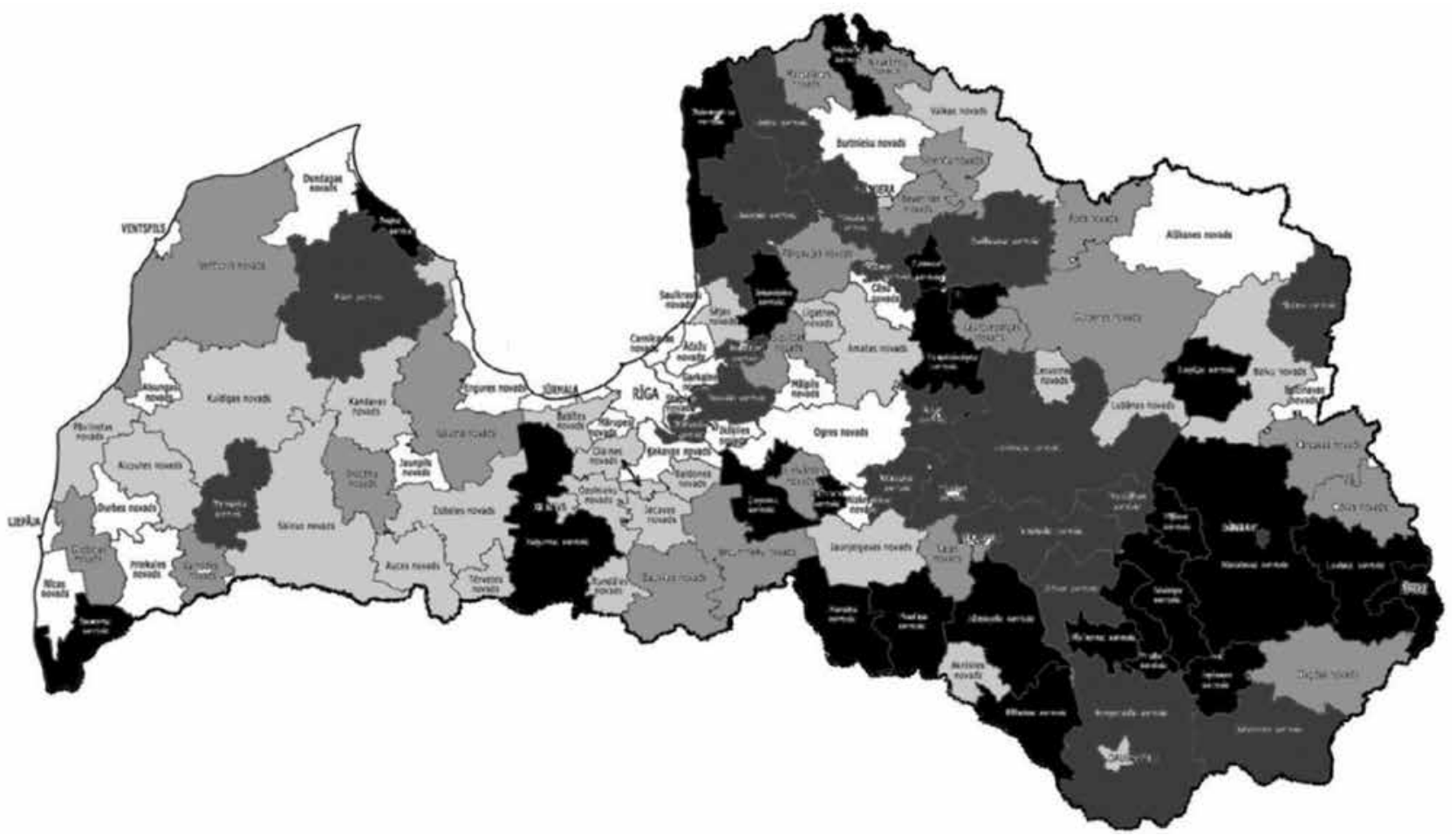

Figure 2. Social-economic security of Latvia's municipal territories according to the data for 2015 
Summarizing the outcomes of the research carried out by A. Smirnovs (Smirnovs et al. 2018), it can be concluded that the level of social-economic security improved in the period $2011-2015$, both in relation to their own indicators, and in relation to other municipalities' indicators in $16 \%$ of Latvian municipalities. The improvement of their own indicator of social-economic security and at the same time its deterioration in relation to other Latvian municipalities is observed in $15 \%$ of municipalities. The deterioration in relation to their own indicators while being ahead of other municipalities is observed in $36 \%$ of the total number of municipalities. The deterioration of their own indicators while increasingly lagging behind other municipalities is observed in $33 \%$ of municipalities (Smirnovs et al. 2018). However, despite the identified trends, the general trend in the dynamics of imbalancies in social-economic security in Latvian municipalities during the period under study remains unclear. Using Barro regressions, coefficients of range and variations of indicators, it is possible to identify what processes of social-economic security and its components are happening in dynamics: convergence or divergence.

The values of the coefficients of variation of municipalities' social-economic security and its components from 2011 to 2015, which measure the range and show the dynamics of inequality are determined. If there is dispersion, the coefficient of variation or other statistical indicators of inequality decrease. It indicates the presence of convergence. Otherwise the indicators differ over time.

Table 1. Values of coefficients of variation of social-economic security indicators and its components in 2011 and 2015

\begin{tabular}{|c|c|c|c|c|}
\hline & Vo 2011 & $\mathrm{V \sigma} \quad 2015$ & $\mathrm{~K}_{\mathrm{R}} 2011$ & $\mathrm{~K}_{\mathrm{R}} \quad 2015$ \\
\hline Social-economic security (\%) & 0.14 & 0.15 & 0.88 & 1.01 \\
\hline 2011 g. $=100 \%$ & 100 & 113 & 100 & 114 \\
\hline General economic F1 (\%) & 0.17 & 0.23 & 0.98 & 1.26 \\
\hline 2011 g. $=100 \%$ & 100 & 131 & 100 & 129 \\
\hline Investment F2 (\%) & 1.36 & 1.59 & 7.52 & 9.32 \\
\hline 2011 g. $=100 \%$ & 100 & 117 & 100 & 124 \\
\hline Industrial F3 (\%) & 0.69 & 0.71 & 4.46 & 5.78 \\
\hline $2011 \mathrm{~g} .=100 \%$ & 100 & 103 & 100 & 130 \\
\hline Educational F4 (\%) & 0.56 & 0.68 & 3.73 & 4.48 \\
\hline 2011 g. $=100 \%$ & 100 & 122 & 100 & 120 \\
\hline Infrastructure F5 (\%) & 0.90 & 0.65 & 5.82 & 4.03 \\
\hline 2011 g. $=100 \%$ & 100 & 72 & 100 & 69 \\
\hline Ecological F6 (\%) & 2.27 & 2.11 & 19.54 & 15.34 \\
\hline 2011 g. $=100 \%$ & 100 & 93 & 100 & 79 \\
\hline Cultural and recreational F7 (\%) & 0.73 & 0.91 & 3.87 & 5.51 \\
\hline 2011 g. $=100 \%$ & 100 & 125 & 100 & 142 \\
\hline Employment F8 (\%) & 0.30 & 0.30 & 1.71 & 1.70 \\
\hline 2011 g. $=100 \%$ & 100 & 101 & 100 & 99 \\
\hline Law enforcement F9 (\%) & 0.16 & 0.18 & 1.18 & 1.26 \\
\hline 2011 g. $=100 \%$ & 100 & 115 & 100 & 107 \\
\hline Provision of social protection and healthcare F10 (\%) & 0.10 & 0.13 & 0.61 & 0.67 \\
\hline 2011 g. $=100 \%$ & 100 & 125 & 100 & 110 \\
\hline
\end{tabular}

Source: Developed by the authors

The authors determined $\sigma$-convergence of the following indicators in Latvian municipalities in the period 2011 - 2015: the infrastructure component F5 - coefficient of variation decreased by $28 \%$, coefficient of range by $31 \%$; the ecological component F6 - coefficient of variation decreased by $7 \%$, coefficient of range by $21 \%$. It is too early yet to estimate $\sigma$-convergence according to the employment component F8. Therefore, in Latvian municipalities for 5 years there is divergence in most indicators, which negatively affects the dynamics of the overall indicator of socio-economic security: the coefficient of variation increased by $13 \%$, the coefficient of range by $14 \%$ (Table 1$)$. 
When investigating $\beta$-convergence, it was found that the investment component $\mathrm{F} 2$, the production component $\mathrm{F} 3$, the infrastructure component F5, the ecological component F6, the cultural and recreational component F7, and the law enforcement component F9 have the coefficient $\beta<0$. Other components have either $\beta>0$ or $p$-value of the model is more than 0.05 (Table 2).

Table 2. Values of coefficients of variation of social-economic security indicators and its components in 2011 and 2015

\begin{tabular}{|l|c|c|}
\hline & coefficient $\beta$ & $\mathrm{p}$-value \\
\hline Social-economic security (\%) & -0.161 & 0.166 \\
\hline General economic F1 (\%) & -0.183 & 0.051 \\
\hline Investment F2 (\%) & -0.493 & 0.005 \\
\hline Industrial F3 (\%) & -0.201 & 0.000 \\
\hline Educational F4 (\%) & 0.007 & 0.909 \\
\hline Infrastructure F5 (\%) & -0.324 & 0.000 \\
\hline Ecological F6 (\%) & -0.194 & 0.012 \\
\hline Cultural and recreational F7 (\%) & -0.329 & 0.000 \\
\hline Employment F8 (\%) & -0.012 & 0.619 \\
\hline Law enforcement F9 (\%) & -0.366 & 0.001 \\
\hline Provision of social protection and healthcare F10 (\%) & -0.117 & 0.173 \\
\hline
\end{tabular}

Source: Developed by the authors

There were several situations determined: $\beta$ - convergence and $\sigma$-convergence; $\beta$ - convergence and $\sigma$ - divergence; $\beta$-divergence and $\sigma$ - divergence (Table 3 ). The first situation " $\beta$ - convergence and $\sigma$ - convergence" explains that a quicker growth of indicators occurs in the regions with lower values of these indicators at the initial period of time, which with time results in the decrease in the coefficient of variation and coefficient of range of indicators in a specific group of regions. The second situation " $\beta$ - convergence and $\sigma$ - divergence" is possible when a group of regions with initially low absolute values of the indicator constantly changes places with regions with initially higher absolute values of the indicator, although the general level of gap between these regions is permanent. The third situation " $\beta$-divergence and $\sigma$ - divergence" is possible if the condition of faster growth of indicators in regions with lower values of these indicators at the initial period of time is not met, which cannot with time lead to the decrease in the coefficient of variation and the coefficient of range of indicators in a certain group of regions. Therefore, $\beta$ - convergence is based on the Solow model and provides the answer to the question whether low-level regions will ever be able to catch up with high-level regions. The interrelation of these concepts is that $\beta$-convergence follows from $\sigma$ - convergence, but there is no opposite consequence (Smirnovs et al. 2018).

Table 3. $\beta$ - convergence and $\sigma$ - convergence of social-economic security and its components in the period $2011-2015$

\begin{tabular}{|l|c|c|}
\hline & $\beta$ - convergence & $\sigma$ - convergence \\
\hline Social-economic security (\%) & no convergence & divergence \\
\hline General economic F1 (\%) & no convergence & divergence \\
\hline Investment F2 (\%) & convergence & divergence \\
\hline Industrial F3 (\%) & convergence & divergence \\
\hline Educational F4 (\%) & no convergence & divergence \\
\hline Infrastructure F5 (\%) & convergence & convergence \\
\hline Ecological F6 (\%) & convergence & convergence \\
\hline Cultural and recreational F7 (\%) & convergence & divergence \\
\hline Employment F8 (\%) & no convergence & divergence \\
\hline Law enforcement F9 (\%) & convergence & divergence \\
\hline Provision of social protection and healthcare F10 (\%) & no convergence & divergence \\
\hline
\end{tabular}

Source: Developed by the authors 
Therefore, it has been found that there are growing disparities of social-economic security in Latvian municipalities in the period $2011-2015$. The values of the coefficients $\beta, V \sigma, K_{R}$ also characterize the growing disparities in the following components: general economic (F1), educational (F4), employment (F8), and provision of social protection and healthcare (F10).

Regarding the investment (F2), industrial (F3), cultural and recreational (F7), and law enforcement (F9) components, the level of disparities is not changing in a situation where a group of municipalities with initially low absolute values of the indicator is constantly changing places with municipalities with initially higher absolute values of the indicator.

The fall in disparities is determined in the infrastructure (F5), and environmental (F6) components, i.e. a faster growth of indicators occurs in municipalities with lower values of these indicators in the initial period of time, which leads with time to the decrease in the coefficient of variation and the coefficient of range of indicators in a certain group of regions.

\section{Conclusions}

In the period from 2011 to 2015 in Latvia at the municipal level the disparities of the generalized indicator of socio-economic security increase, which is confirmed by the determined $\beta$ - divergence and $\sigma$-divergence. The biggest disparities have been determined in general economic (F1), educational (F4), employment (F8), and provision of social protection and healthcare (F10) components. Perhaps, the key factor of the growing diparities is the decrease in the number of population in provincial municipalities because of the emigration of young people, high death and low birth rates, which in turn leads to the reduction in social and educational facilities: hospitals, educational institutions, etc. The decrease in disparities has been determined in infrastructure (F5) and ecological (F6) components. The convergence of these components might be explained by the use of the EU funds for the improvement of infrastructure and ecology, as well as by the fall in industrial activities, which also positively affects the ecology. However, this issue requires a more thorough and detailed further investigation.

\section{References}

Abdullah, O., Khalizani, K., Fatima Mohsen, A. (2019). Exploring the role of safety culture factors towards safety behaviourin smallmedium enterprise. International Journal of Entrepreneurship, 23(3), 1-11.

Barro R., Sala-i-Martin X. (1991). Convergence across States and Regions. Brookings Papers on Economic Activity, 1, $107-158$.

Barro R.J., Sala-i-Martin X. (1992). Convergence. Journal of Political Economy, 100 (2), 223-251.

Barro R.J., Sala-I-Martin X. (1995). Economic Growth. Chicago: The MIT Press

Buzan, Barry. (2007). People, States \& Fear: An Agenda for International Security Studies in the Post-Cold War Era. ECPR Classics Series.

Čizo, E., Ignatjeva, S., Lavrinenko, O. (2018). Assessment of Convergence Processes of Financial Depth Indicators in States with Different Levels of Economic Development. Journal of Security and Sustainability Issues, 7(3), 459-476. https://doi.org/10.9770/jssi.2018.7.3(8)

Cristiano Freitas Gomes, Márcia De Mello Costa De Liberal, \& Chennyfer Dobbins Abi Rached. 2019. Cost management in a multiProfessional small-Scale clinic of popular health services. International Journal of Entrepreneurship, 23(2), 1-13.

Energy Transformation towards Sustainability. 1st Edition. Editors: Manuela Tvaronavičiene Beata Slusarczyk. ISBN: 9780128176887 Imprint: Elsevier Published Date: 1st November 2019. https://www.sciencedirect.com/book/9780128176887/energy-transformationtowards-sustainability

Fabus, M., Dubrovina, N., Guryanova, L., Chernova, N., Zyma, O. (2019). Strengthening financial decentralization: driver or risk factor for sustainable socio-economic development of territories. Entrepreneurship and Sustainability Issues, 7(2), 875-890. http://doi. org/10.9770/jesi.2019.7.2(6)

Filipishyna, L., Bessonova, S., Venckeviciute, G. (2018). Integral assessment of developmental stability: cases of Lithuania and Ukraine. Entrepreneurship and Sustainability Issues, 6(1), 87-99. http://doi.org/10.9770/jesi.2018.6.1(7) 
Gagarina, G. Y., Sorokina, N. Y., Chainikova, L. N., Sizova, D. A., Nadyrov, S. M. (2019). Tools to ensure the economic security of the old industrial regions, Entrepreneurship and Sustainability Issues, 7(1), 747-762. https://doi.org/10.9770/jesi.2019.7.1(53)

Hacker, J.S., Huber, G., Nichols, A., Rehm, P., Schlesinger, M., Valletta, R.G., Craig, S. (2012). The Economic Security Index: A New Measure for Research and Policy Analysis. Retrieved May 9, 2019, from http://www.frbsf.org/economic-research/files/wp12-21bk.pdf https://doi.org/10.1016/C2018-0-02510-4, p.348

Huber, G., Rehm, P., Schlesinger, M., Valletta, R. (2010). Economic Security at Risk: Findings from the Economic Security Index. Retrieved April 26, 2019, from http://www.economicsecurityindex.org

Islam, N. (2003). What have We Learnt from the Convergence Debate? Journal of Economic Surveys, 17(3), 309-362. https://doi. org/10.1111/1467-6419.00197

Kalyugina, S., Pianov, A., Tvaronavičienè, M, Sorokin, G. 2018. Depopulation and external migration as the institutional risks to personnel safety, Journal of institutional studies, 10(4): 125-144. https://doi.org/10.17835/2076-6297.2018.10.4.125-144

Kosiedowski, W., Lavrinenko, O. (2014). Statistical Methods for Analysis of Regional Development as a Multidimensional Socioeconomic Phenomenon. In A.Ignasiak-Szulc, W.Kosiedowski (Ed.) Problems of Economic Policy of the Central and Eastern Europe Countries Macroeconomic and Regional Aspects (pp.457-484). Torun (Poland): Wydawnictvo naukowe uniwersytetu Mikolaja Kopernika. ISBN 978-83-231-3285-1

Lavrinenko O. (2015). Living standard of Central and Eastern Europe, 146 p. Germany: GlobeEdit, ISBN 978-3-639-74780-5

Lavrinenko O. (2010). Overview of Quantitative Methods for Building of Integral Indicators. Regional review, Research papers, 6. Daugavpils: Daugvpils Universuty Academic Press "Saule"

Lavrinenko, O., Lavrinovica, I. (2013). Integralo indikatoru konstruesana [Design of integrated indicators]. Macibu metodiskais lidzeklis. Daugavpils: Daugavpils Universitates akadeemiskais apgads “Saule”. ISBN 978-9984-14-645-4.

Lavrinenko, O., Smirnov, A., Jefimovs, N. (2016). Assessment of social-economic security of administrative areas of Latvian municipalities. Journal of Security and Sustainability Issues, 6(2), 245-257. http://dx.doi.org/10.9770/jssi.2016.6.2(5)

Masood, O., Tvaronavičienė, M., Javaria, K. (2019). Impact of oil prices on stock return: evidence from G7 countries. Insights into Regional Development, 1(2), 129-137. https://doi.org/10.9770/ird.2019.1.2(4)

Mikhaylov, A.S., Mikhaylova A.A., Savchina, O.V. (2018). Innovation security of cross-border innovative milieus, Entrepreneurship and Sustainability Issues 6(2): 754-766. http://doi.org/10.9770/jesi.2018.6.2(19)

Moumen, Z., El Idrissi, N.E.A., Tvaronavičienè, M., Lahrach, A. (2019). Water security and sustainable development. Insights into Regional Development, 1(4), 301-317. https://doi.org/10.9770/ird.2019.1.4(2)

Nikitina, M.G., Pobirchenko, V.V., Shutaieva, E.A., Karlova, A.I. (2018). The investment component in a nation's economic security: the case of the Russian Federation, Entrepreneurship and Sustainability Issues 6(2): 958-967. http://doi.org/10.9770/ jesi.2018.6.2(32)

Ohotina, A., Lavrinenko, O., Gladevich, J., Lazdans, D. (2018b). The investment climate in Latvia's, Lithuania's and Belarus's crossborder regions: the subjective-objective assessment. Entrepreneurship and Sustainability Issues, 6(2), 767-780. http://doi.org/10.9770/ jesi.2018.6.2(20)

Ohotina, A., Lavrinenko, O., Ignatjeva, S., Lonska, J. (2018a). Socio-economic security as a determinant of regional differences in the investment climate in the region. Journal of Security and Sustainability Issue, 7(3), 427-438. https://doi.org/10.9770/jssi.2018.7.3(5)

Olayinka A. Abiodun, Emmanuel K.Agbaeze, Bamidele S.Adeleke, Nwanneka C. Ghasi., \& Anthony O.Ude. (2019). Do leadership roles affect survivability of family businesses in developing economies? . International Journal of Entrepreneurship, 23(2), 1-10.

Rezk, M.R., Radwan, A., Salem, N.M., Sakr, T.M., Tvaronavičienė, M. (2019). Foresight for sustainable energy policy in Egypt: results from a Delphi survey. Insights into Regional Development, 1(4), 357-369. https://doi.org/10.9770/ird.2019.1.4(6)

Rezk, M.R., Radwan, A., Salem, N.M., Sakr, T.M., Tvaronavičienė, M. 2019. Foresight for sustainable energy policy in Egypt: results from a Delphi survey. Insights into Regional Development, 1(4), 357-369. https://doi.org/10.9770/ird.2019.1.4(6)

Sala-i-Martin X. (1996b). The Classical Approach to Convergence Analysis. The Economic Journal, 106(437), $1019-1036$.

Sala-i-Martin, X. X. (1996a). Regional cohesion: evidence and theories of regional growth and convergence. European Economic Review, 40(6), 1325-1352. https://doi.org/10.1016/0014-2921(95)00029-1 
Schwarz, D. (2018). The ability of listed companies to optimize their capital structure, shape their distribution policy and fight hostile takeovers by repurchasing their own shares, Entrepreneurship and Sustainability Issues 6(2): 636-648. https://doi.org/10.9770/ jesi.2018.6.2(12)

Senchagov, V. (2002). Ekonomicheskaya bezopasnost, geopolitika, globalizatsiya, samosohranenie i razvitie [Economic security, geopolitics, globalization, self-preservation and development]. Moskva, Finstatinform.

Škuflić, L., Krpan, M., Žmuk, B. (2018). Migration and the economic crisis in the European Union member states: cluster analysis, Entrepreneurship and Sustainability Issues 6(2): 979-1000. https://doi.org/10.9770/jesi.2018.6.2(34)

Smirnovs A., Lavrinenko O., Tumalavičius V. (2018). Analysis of social-economic security of administrative areas in Latvian municipalities. Journal of Security and Sustainability Issues, 7(4), 817-829. http://dx.doi.org/10.9770/jssi.2018.7.4(17)

Tambovtsev, V.L. (1995). Ekonomicheskaya bezopasnost hozyaystvennyih sistem: struktura, problemyi [Economic security management systems: structure, problems]. Vestnik MGU. Seriya 6 «Ekonomika». \#3.

Tvaronavičienė M. (2018a). Towards internationally tuned approach towards critical infrastructure protection, Journal of Security and Sustainability Issues 8(2): 143-150. https://doi.org/10.9770/jssi.2018.8.2(2)

Tvaronavičienè, M. (2018b). Toward efficient policy making: forecasts of vulnerability to external global threats, Journal of Security and Sustainability Issues 7(3): 591-600. https://doi.org/10.9770/jssi.2018.7.3(18)

Tvaronavičienè, M. (2019). Insights into global trends of capital flows' peculiarities: emerging leadership of China. Administratie si Management Public, (32), 6-17, https://doi.org/10.24818/amp/2019.32-01

Tvaronavičienè, M., Masood, O., Javaria, K. (2018). Preconditions of the Eurozone economic security: how to overcome liquidity risk and cost inefficiency in leading banks of UK and Germany, Polish journal of management studies, 18(1) 418-427. https://doi. org/10.17512/pjms.2018.18.1.31

Veli Sibiya., \& Tumo Kele. (2019). Barriers and Public Policies Impeding Smes' International Market Expansion: A South African Perspective. International Journal of Entrepreneurship, 23(1), 1-19.

\section{Aknowledgements}

This article is published within research project of Daugavpils University "Assessment of Social-Economic Security of Administrative Areas of Latvian Municipalities in Dinamic of 2011 - 2016" No 14-95/6

Andrey SMIRNOV Mg.oec., Ph.D. student, Faculty of Social Science, Daugavpils University, Latvia. Research interests: Regional Economics, Economic and Social Security; Issues of Regional Security and Sustainability.

ORCID ID: https://orcid.org/0000-0002-1352-5135

Olga LAVRINENKO is Dr. oec, Leading researcher at the Institute of Humanities and Social Sciences of Daugavpils University, Latvia. She has status of experts of the Latvian Council of Science in the field of economics and entrepreneurship. Her research interests: regional economics, sustainable economic development.

ORCID ID: https://orcid.org/0000-0001-7383-3749.

Alina OHOTINA is Dr.oec, Researcher at the Institute of Humanities and Social Sciences of Daugavpils University, Latvia. She has the status of Expert of the Latvian Council of Science in the fields of economics and entrepreneurship, sociology and social work. She is Expert of the Foundation for Polish Science under Measure 4.4 of the Smart Growth Operational Programme 2014-2020 and Expert of Polish National Agency for Academic Exchange. Her research interests: regional economics, investments, sustainable development, investment climate (entrepreneurial environment).

ORCID ID: https://orcid.org/0000-0002-2749-2725

Halina SHMARLOUSKAYA is Doctor hab. of Economics, Professor at the International Business Department of the Faculty of International Economic Affairs of the Belarusian State Economic University. She is Chairman of Scientific Council for defense of doctoral thesis $(\mathrm{PhD})$ in Economics and World Economy, Republic of Belarus, Member of the Expert Council for Draft State Programs (section on Economics and Finance) at the Council of Ministers of the Republic of Belarus, Expert of the State Committee for Science and Technology. Her research interests: international economics, international trade, TNC, networking economy, international investments and trade, economies in transition.

ORCID ID: https://orcid.org/0000-0001-9534-1251 
Alina BETLEJ is an assistant professor at the Department of Social Microstructures and Modern Sociological Theories of the Faculty of Social Sciences of the John Paul II Catholic University of Lublin (Poland). She is an Expert of the Foundation for Polish Science and the Polish National Agency for Academic Exchange, a member of the board of The Polish Association for Technology assessment, editor of e-edition of The Interdisciplinary Journal "Transformations", member of The Educational Foundation "Transformations". She is an author of many experts opinions in the Lublin Region. She took part in many scientific projects. She is interested in network theories, impact of digitalization on society and economy, sustainable development of smart societies, transformations of techno-social systems. ORCID ID: https://orcid.org/0000-0002-2729-6564 